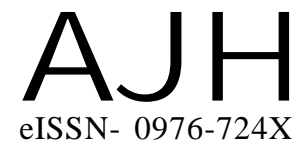

Received : 06.10.2015

Revised : 10.04.2016

Accepted : 22.04.2016

Members of the Research Forum

Associated Authors:

${ }^{1}$ Mahatma Gandhi Chitrakoot

Gramodaya Vishwavidyalaya,

Chitrakoot, SATNA (M.P.) INDIA

${ }^{2}$ Department of Horticulture, College of Agriculture, C.S.A. University of Agriculture and Technology,

KANPUR (U.P.) INDIA

Author for correspondence :

H.M. SINGH

Mahatma Gandhi Chitrakoot

Gramodaya Vishwavidyalaya,

Chitrakoot, SATNA (M.P.) INDIA

Email : hmsingh1983@gmail.com
THEASIAN JOURNALOF HORTICULTURE

Volume $11 \mid$ Issue $1 \mid$ June, 2016 |40-43

Visit us -www.researchjournal.co.in

RESEARCH PAPER

DOI : 10.15740/HAS/TAJH/11.1/40-43

\title{
Study on phenotypic correlation co-efficient in Dahlia germplasm
}

\section{H.M. SINGH, UMA SHANSHKAR MISHRA ${ }^{1}$ AND A. PRASAD ${ }^{2}$}

ABSTRACT : Dahlia is an important bulbous flower crop which has position to increase economic earning of grower. Forty varieties were grown and studied for genotypic correlation of traits at C.S.Azad University of Agriculture and Technology, Kanpur, during 2011-12 and 2012-13. Vegetative and reproductive characters parameters were found to have considerable relationship which also indicated the scope for making improvement in dahlia. Plant height and maximum number of flower per head revealed the sustainable magnitude for crop improvement in dahlia crop.

KEY WORDS : Species, Varieties, Germplasm, Dahlia

HOW TO CITE THIS ARTICLE : Singh, H.M., Mishra, Uma Shanshkar and Prasad, A. (2016). Study on phenotypic correlation co-efficient in Dahlia germplasm. Asian J. Hort., 11(1) : 40-43, DOI : 10.15740/ HAS/TAJH/11.1/40-43. 